\title{
Relevance of Educational Media and Multimedia Technology for Effective Service Delivery in Teaching and Learning Processes
}

\author{
Omodara O.D. (M.Ed); Adu E.I. (M.Ed) \\ Department Of Curriculum Studies Center For Educational Technology College Of Education Ikere Ekiti, Ekiti \\ State Nigeria \\ Department Of Curriculum Studies Center For Educational Technology College Of Education Ikere Ekiti, Ekiti \\ State Nigeria
}

\begin{abstract}
This study was focused at examining the relevance of educational media and multimedia technology for effective service delivery in teaching and learning processes. It also highlighted the various classifications of educational media and multimedia technology with diagram and tabular illustration. Using relevant content analysis method, pertinent empirical evidences that revealed positive effects on learning from computer and television technology programs were re-visited. Relevant conclusion and recommendation were made that educational media and technology is inestimable in teaching and learning activities and the Federal and State Governments, Non Governmental Organisations and School Administrators should embrace it.

Keywords: Media, Multimedia, Service, Teaching and Learning.
\end{abstract}

\section{Introduction}

Educational media and technology can be defined as all means of communication like prints, graphics, animations, audios and audiovisuals. Educational multimedia technology incorporates all the qualities of prints, graphics, animations, audio and audiovisuals and technology is defined as any object or process of human origin that can be utilised to convey media and multimedia. In this sense, technology includes phenomena as diverse as books, films, television, and the internet. In education, media are the symbol systems that teachers and learners utilise in representing knowledge and technologies are the tools that allow them to share their knowledge representations with others (Thomas, 1998).

Educational media and multimedia technology are the channels of transmitting information to learners' and are also those gadgets, and machines that are needed in transmitting information to learners'. There are various types of educational media and multimedia technology currently utilised in teaching and learning processes which are: computer system, microphone, mobile device, interactive whiteboard, digital-video-ondemand, online media stream, digital game, pod-cast and so on. Computer system relevance in the classroom allows teachers to demonstrate a new lesson, animate, present new materials, illustrate how to use new programs and show new websites. In a noisy classroom or large classes, learners will be able to hear their teachers' instruction clearly and in the process learn better with the use of microphones (Webcrawler, 2013).

Mobile devices such as clickers or smartphones can be utilised in enhancing feedback activities during and after instruction delivery by the teacher. An interactive whiteboard provides touch control of computer applications which enhance the experience in the classroom by displaying visuals that can be viewed on a wider screen by learners'. This assist in visual learning, and interactivity for learners' to draw, write or manipulate images on the interactive whiteboard. The digital video eliminates the need for in-classroom hardware players and allows teachers and learners to access video clips immediately without the internet access. Online media streams can enhance streamed video websites for classroom teaching and learning processes. The digital game motivates the learners in learning a particular concept at hand and its use is increasing everyday. Podcast is relatively new invention that allows teachers to publish files to the internet where learners' can subscribe and receive new files from people by a subscription (Thomas, 1998).

\section{Relevance of Educational Media and Multimedia Technology}

\section{Literature Review}

Computer-based technologies cannot be regarded as media, because the variety of programs, tools, and devices that can be utilised with them is neither limited to a particular symbol system, nor to a particular class of activities. In this light, the computer is in fact a multifaceted invention of many uses, a symbolic tool for making, exploring, and thinking in various domains. It is utilised to represent and manipulate symbol systems, language, mathematics, music, and to create symbolic products, poems, mathematical proofs, compositions and so on (Salomon, 1992). The personal computer is the most common interactive technology utilised as a teaching machine today. Interactive instruction via personal computer is known by many names and acronyms such as 
computer-based instruction (CBI) (Alessi \& Trollip, 1991), integrated learning systems (ILS) (Bailey, 1993), and intelligent tutoring systems (ITS) (Polson \& Richardson, 1988).

The personal computer as a tutor or surrogate instructor has been the subject for much research and evaluation since its development in the late 1970s (Coley, Cradler, \& Engel, 1997; Hannafin, Hannafin, Hooper, Rieber, \& Kini, 1996). The earliest forms of computer-based instruction were heavily influenced by the behavioral psychology of Skinner (1968). These programs were essentially automated forms of programmed instruction. They presented information to the learners' in small segments, required the learners' to make overt responses to the information as stimulus, and provided feedback to the learners' along with differential branching to other segments of instruction or to drill-and-practice routines. Computers as tutors have positive effects on learning as measured by standardized achievement tests, and were more motivating for learners, accepted by more teachers than other technologies, and were widely supported by administrators, parents, politicians, and the public (Coley, et.al, 1997).

The most positive research news about learning from television can be found in the classroom where 40 years of research showed positive effects on learning from television programs that were explicitly produced and utilised for instructional purposes (Dorr, 1992, Seels, Berry, Fullerton \& Horn, 1996). In addition, most studies showed that there were no significant differences in effectiveness between live teacher presentations and videos of teacher presentations (Seels, et.al, 1996).

More importantly, there is strong evidence that television is utilised most effectively when it is intentionally designed for education and when teachers are involved in its selection, utilization, and integration into the curriculum (Johnson, 1987). In the past, the biggest barrier to the integration of television programs into the classroom was the fixed-time limitation of instructional broadcasts, but the wide-spread availability of video cassette recorders (VCRs) has provided teachers with the ease-of-use and flexibility they require (Mielke, 1990). Increasingly television is coming into schools via cable and satellite transmissions. The Star Schools Consortium in the United State of America (USA) is one of the largest of such enterprises, providing telecourses in thousands of schools across the nation (Moore \& Kearsley, 1996). Most often, programs received via satellite dish or cable are recorded by media specialists or technology coordinators and subsequently made available for teachers when and how they choose. Flexibility of scheduling and ease of access to equipment and television programs are the biggest factors promoting classroom use of television (Dorr, 1992; Seels et. a1, 1996).

\section{Effective Service Delivery in Teaching and Learning Processes}

According to Yoon \& Hoon (2009), in order to have effective service delivery in teaching and learning the use of educational media and multimedia technology is paramount and higher education media and multimedia technology service delivery has had a dramatic impact on teaching and learning, especially with the ready access to new technologies, educational institutions are well positioned to take advantage of these rapid changes. There are a number of ways that educational media and multimedia technology can enhance effective service delivery programs while conserving program resources through:

\section{(1)Program Management}

Databases can help program staff to track learners' placements, community partner contact information and the academic calendar.

\section{(2)Community Partner Participation}

A well-publicized web site can describe the service delivery programs to enhance co-operative learning within the community, and provide easy access to forms for registering a community project and highlight stories of positive community partner experiences.

\section{(3)Curricular Tools}

Online modules and case studies can enhance classroom and community-based learning.

\section{(4)Community Service}

Meaningful community service doesn't necessarily have to involve regular or on-going face-to-face contact between learner and community partner, and it can entail, meeting with community learners in a web design course with a service-learning component.

\section{(5)Reflection}

Electronic discussion groups can enable learners across different service-learning sites to regularly communicate, share their experiences and respond to reflective questions posed by faculty and one another.

\section{(6) Program Evaluation}

Online surveys can enable learners and community partners to respond to questions about their experiences and the impact of the program. Databases can facilitate the tracking and storage of program evaluation information. 


\section{What is Educational Media?}

Educational media refers to channels of communication that carry messages with an instructional purpose. They are usually utilised for the sole purpose of learning and teaching (Webcrawler, 2013).

\section{Classification of Educational Media}

There are different ways to classify media. Print media, non-print media, and electronic media.

(1)Print media: They include: books, journals, magazines, newspapers, workbooks, and textbooks

(2)Non-print media: They include: projected and non-projected media.

(3)Electronic media: They include audio media, visual media and audio-visual, projected media and non-projected media

(i)Projected media: They require light source for projection, for example, film projector slides, and so on.

(ii)Non-projected media: They do not require light source. They include 3dimensional objects, 2dimensional objects, prints, charts, models and so on.

(4)Audio media, Visual media \& Audio-visual

Audio media: This form of media carry sounds alone, for example audio tapes, record player,

(i)Visual media: These are the ones that can be seen. For example, television, computer, white board

(ii)Audio-Visual: This term refers to those instructional materials which provide learners with audio and visual experiences by appearing to the hearing and seeing senses at the same time, for example television, video tapes, and closed circuit television (CCTV).

\section{(5)Hardware and Software}

(i)Hardware: This is the classification of machines or equipment utilised in the instructional process. It is upon these gadgets that the software is transmitted, for example television set, tape recorder and so on.

(ii)Software: this classification consists of all materials used with the machine. They are the real carrier of knowledge or information. They include, films, tapes transparencies.

Diagram 1.

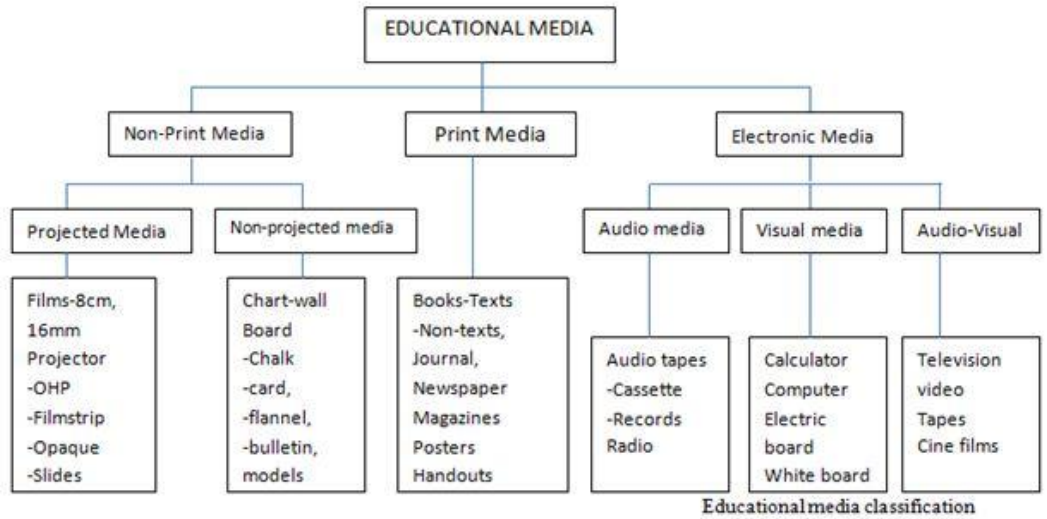

Blog, (2012).

\section{What is Educational Multimedia?}

Multimedia is media and content that uses a combination of different content forms. This contrasts with media that use only rudimentary computer displays such as text-only or traditional forms of printed or handproduced material. Multimedia includes a combination of text, audio, still images, animation, video, or interactivity content forms (Vaughan, 1993).

Multimedia is usually recorded and played, displayed, or accessed by information content processing devices, such as computerized and electronic devices, but can also be part of a live performance. Multimedia devices are electronic media devices used to store and experience multimedia content. Multimedia is distinguished from mixed media in fine art; by including audio, for example, it has a broader scope (Vaughan, 1993).

Classification and Definition of Multimedia Content. Table 1.

\begin{tabular}{|l|l|l|}
\hline Classification & Definition \\
\hline $\begin{array}{l}\text { Education } \\
\text { content }\end{array}$ & Solely for educational purposes & $\begin{array}{l}\text { Two-way learning program consisting of } \\
\text { images, sounds, graphics and text }\end{array}$ \\
\cline { 2 - 3 } & $\begin{array}{l}\text { For edutainment } \\
\text { purposes }\end{array}$ & $\begin{array}{l}\text { Education content mixed with game } \\
\text { elements }\end{array}$ \\
\hline
\end{tabular}


Relevance Of Educational Media And Multimedia Technology For Effective Service Delivery In

\begin{tabular}{|c|c|c|}
\hline \multirow[t]{2}{*}{$\begin{array}{l}\text { Multimedia } \\
\text { publishing }\end{array}$} & Digital books & $\begin{array}{l}\text { Content to deliver knowledge, such as } \\
\text { encyclopedia, dictionaries of specialized } \\
\text { subjects and digital books that are used in } \\
\text { the multimedia devices such as PC }\end{array}$ \\
\hline & $\begin{array}{l}\text { Web products and digital } \\
\text { publishing }\end{array}$ & $\begin{array}{l}\text { Regularly or irregularly published contents } \\
\text { such as web products, digital newspapers, } \\
\text { online magazines and image novels }\end{array}$ \\
\hline \multirow[t]{3}{*}{ Games } & Arcade games & $\begin{array}{l}\text { Games for game-selling shops that use } \\
\text { printed circuit board (PCB) or a separate } \\
\text { exclusive hardware }\end{array}$ \\
\hline & Video games & $\begin{array}{l}\text { Games using TV monitors or exclusive } \\
\text { devices }\end{array}$ \\
\hline & PC games & PC-based games (including online games) \\
\hline \multirow[t]{3}{*}{ Digital images } & Specially edited images & $\begin{array}{l}\text { Specially edited images and computer } \\
\text { graphic works to be used for broadcasting, } \\
\text { movies and advertising }\end{array}$ \\
\hline & $\begin{array}{l}\text { Digital animation and } \\
\text { cartoons }\end{array}$ & $\begin{array}{l}\text { Animation and cartoons that use computer } \\
\text { graphics }\end{array}$ \\
\hline & Digital characters & $\begin{array}{l}\text { 2- and 3-dimensional shape models that } \\
\text { are digitized for commercial purposes and } \\
\text { personality elements model }\end{array}$ \\
\hline \multicolumn{2}{|c|}{ Tools to produce multimedia contents } & $\begin{array}{l}\text { Application software used for production of } \\
\text { contents }\end{array}$ \\
\hline \multicolumn{2}{|l|}{ Others } & $\begin{array}{l}\text { Items other than abovementioned, such as } \\
\text { simple CG works, development of sound } \\
\text { effects and treating of data and images. }\end{array}$ \\
\hline
\end{tabular}

Yoon \& Hoon (2009)

\section{Conclusion and Recommendation}

The relevance of educational media and multimedia technology is inestimable in teaching and learning activities if the most suitable and effective service delivery is adopted within the classroom setting. As the educational media and multimedia technology industry continues to grow, educators should endeavor to develop abilities and skills in the educational media and multimedia technology design and development for instructional purposes. Efforts should also be made by the Federal Government (FG), State Governments, and all school administrators in ensuring that educational media and multimedia technology is included within the school curriculum in the elementary, middle and high school levels to increase the awareness of the essentiality of this concept to all learners'. Non Governmental Organisations (NGOs') should be encouraged in the running of educational media and multimedia technology programs to re-educate the existing populace systematically, so that various educational media and multimedia technology programs will be available to learners'.

\section{References}

[1]. Alessi, S.M. \& Trollip, S.R. (1991). Computer Based Instruction: Methods and Development. New Jersey: Englewood Cliffs

[2]. Bailey, G.D. (1993). Computer Based Integrated Learning Systems. New Jersey: Englewood Cliffs.

[3]. Blog, E. (2012). Classification of Educational Media. Arizona: Retrieved from,

http://edutech202.blogspot.com/2012/12/classification-of- media.html\#!/2012/12/classification-of- media.html on August, 12013.

[4]. Coley, R.J. Cradler, J. \& Engel, P.K. (1997). Computers and Classrooms: The Status of Technology in USA Schools. New Jersey: Policy Information Report.

[5]. Dorr, A. (1992). Television. New York: Encyclopedia of Educational Research, Macmillan Publishers.

[6]. Hannafin, M.J. Hannafin, K.M. Hooper, S.R. Reiber, L.P. \& Kini, A.S. (1996). Research with Emerging Technologies. New York: Macmillan.

[7]. Johnson, J. (1987). Electric Learning: From Audiotape to Videodisc. New Jersey: Lawrence Erlbaum.

[8]. Mielke, K.W. (1990). Research and Development at the Children Television Workshop. New York: Edu-Tech Research and Development, 38(4) 7-16.

[9]. Moore, M.G. \& Kearsley, G. (1996). Distance Education: A Systems View. Belmont: Wadsworth.

[10]. Polson, M.C. \& Richardson, J.J. (1988). Foundations of Intelligent Tutoring Systems. New Jersey: Lawrence Erlbaum.

[11]. Salomon, G. (1992). New Information Technologies in Education. New York: Macmillan.

[12]. Seels, B. Berry, L.H. Fullerton, K. \& Horn, L.J. (1996). Research on Learning from Television. New York: Macmillan.

[13]. Skinner, (1998). The Technology of Teaching. New York: Appleton-Century- Crofts. Library of Congress Card Number 68$12340 \mathrm{E} 81290$.

[14]. Thomas, C.R (1998). The Impact of Media and Technology in Schools. Georgia: Research Report, Retrieved from it.coe.uge.edu/9treeves.pdf July, 31/13.

[15]. Vaughan, T. (1993). Multimedia: Making It Work. Berkeley: Retrieved from, http://en.wikipedia.org/wiki/Multimedia on August $1,2013$.

[16]. Webcrawler, C. (2013). Definition of Educational Media. California: Retrieved from http://www.ask.com/question/meaning-ofeducational-media on August, 12013.

[17]. Yoon J.S. \& Hoon S.S. (2009). A Study on the Direction of Education to Prevent Multimedia Illiteracy. Korea: Retrieved from http://wwwimages.adobe.com on August 1, 2013. 